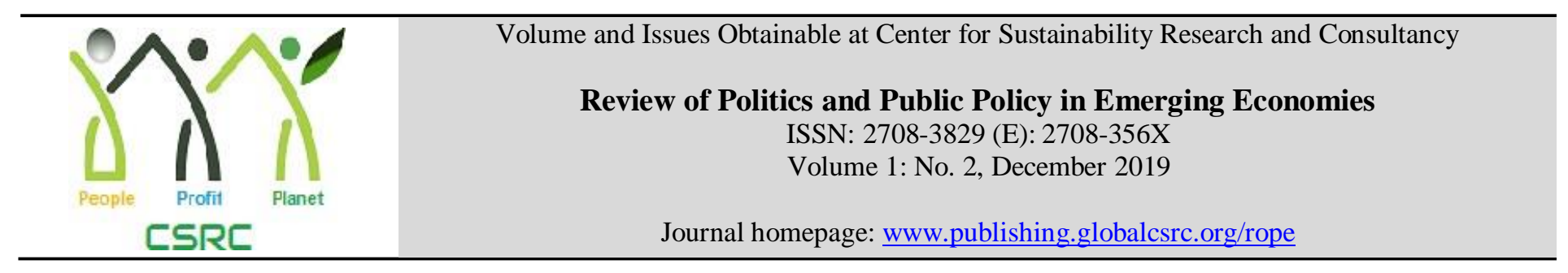

\title{
The Impact of Corporate Governance Attributes on Tax Planning of listed Manufacturing Companies: A Comparative Study between Nigeria and Malaysia
}

\author{
${ }^{1}$ Sule Ba'aba, ${ }^{2}$ Mahmud Bashiru \\ ${ }^{1}$ Department of Accounting Federal University Gashua-Nigeria, baabasule2014@gmail.com \\ ${ }^{2}$ Graduate School of Business, Universiti Sains Malaysia, otaidaeikojonwa@gmail.com
}

ARTICLE DETAILS
History
Revised format: November 2019
Available Online: December 2019

Keywords

Corporate Governance Attributes, Tax planning, Listed companies, Nigeria, Malaysia

JEL Classification:

MO, M12

\section{ABSTRACT}

The serious decline in the price of crude oil in recent years has led the state government to look for new sources of revenue and becomes strict and aggressive to the assessment and collection of revenue from the existing sources. This study examines the impact of Corporate Governance Attributes on Tax planning of listed manufacturing companies in Nigeria and Malaysia. The corporate governance parameters include board size and CEO tenure while tax planning is proxied by the effective tax rate and firm size as control variable. The objective is to determine if there is a relationship between corporate governance attributes and tax planning which in turn may improve firm performance. The study adopts comparative and ex-post facto research design and will utilize panel data from annual reports and accounts of the listed companies for the period of five years (2014-2018). The Data were analysed using a panel regression technique to assess the effect of the independent variables on the dependent variable. Hausman specification test was conducted to choose between fixed and random effect estimation and the p-value is 0.9863 which insignificant. The results from random effect estimation model indicates a negative and significant relationship between CEOT, FSIZE and ETR and a positive relationship between BSIZE and ETR. Therefore, the study concludes that corporate governance mechanism plays a significant role in tax planning and Nigerian manufacturing companies pays high tax charges as compare to Malaysian food and beverages companies.

\section{OPEN ACCESS}

(C) 2020 The authors, under a Creative Commons Attribution-

NonCommercial 4.0

Corresponding author's email address: baabasule2014@gmail.com

Recommended citation: Ba'aba, S. \& Bashiru, M. (2019). The Impact of Corporate Governance Attributes on Tax Planning of listed Manufacturing Companies: A Comparative Study between Nigeria and Malaysia: 1999-2015. Review of Politics and Public Policy in Emerging Economies, 1(2), 105-112

\section{Introduction}

The serious decline in the price of crude oil in recent years has led the federal government (FG)to look for new sources of revenue and becomes very strict and aggressive to the mode of assessment and collection of revenue from the existing sources(Dennis \& Emmanuel, 2014). Tax is one of the major sources of revenue to the government because of its certainty, consistency and the mandate government has to impose taxes. Taxes on corporate profits are mandatory and usually constitute a large outflow for firms in Nigeria and if not planned properly could lead to 
disproportionate and unwilling transfer of corporate resources to the government which may affect the operating capacity and value of the firm. Given the ambitious revenue target from non-oil sources by FG. The tax authorities are becoming more aggressive in their efforts to shore up tax revenue (KPMG, 2018). Following that series of tax cases (Companies Income Tax) have generated a significant debate over the last few years e.g Citibank vs FIRS, TSKJ Construcoes Internacional Sociadede Unipersonal LDA vs FIRS, CNOOC \& SAPETRO vs NNPC \& FIRS (KPMG, 2018) among others. The Tax Appeal Tribunal (TAT) jurisdiction on matters pertaining to the revenue of the FG and the taxation of companies has created lot of arguments among the stakeholders. One of the major challenges of corporate entities is high tax rate and multiple taxes that lead to high tax burden.

Tax planning is part of financial plans that offer an opportunity to mitigate the tax liability and improve the income of an organization. Firms that maximize the loopholes in the tax law tend to lower its tax burden. Taxes are deductions from the cash flow of a firm and the income distributable to the shareholders. The benefit of increased cash flow from tax avoidance practices will be accomplished but with certain associated cost(Annuar, Salihu, \& Obid, 2014).

Although tax planning can increase earnings but there are actual and potential cost that restrain firms from maximizing profits through tax planning. In addition to direct cost in the form of salaries and fees, indirect cost can arise, for instance when corporate restructuring is a necessary condition for obtaining the desired tax benefits. Potential costs can exist to the extent that tax planning can be challenged by tax administration which can then lead to reputational cost.

Tax planning has been viewed as benefiting shareholders via increased after-tax earnings. It is argued that when an information asymmetry exists between managers and shareholders with respect to tax planning, it facilitates managers to act in their own interests and that will result to a negative association between tax planning and firm value(Abdul Wahab \& Holland, 2012).

\section{Problem Statement, Research Questions and Objectives}

There is still a considerable debate over whether corporate governance attributes impact on the tax planning of corporate entities. For instance, in the United State Păunescu, Vintilă and Gherghina, (2016), explored the relationship between corporate governance characteristics and effective tax rate of the US listed firms. Using a sample of 50 companies, mainly from the technology area, listed on NASDAQ over the period 2000- 2013 and panel data regression. They found that board independence and board size have a statistically negative and significant impact on the corporate tax rate while CEO ownership and CEO tenure have mixed association with corporate tax. On the other hand, in Malaysia Annuar et al., (2014), empirically investigates the relationship between corporate ownership structure and corporate tax avoidance. They concluded that based on cost and benefit of tax avoidance that family, foreign and government ownership are associated with corporate tax avoidance among Malaysian listed companies.

Prior studies have investigated the effects of various firm-specific characteristics on tax planning (Annuar et al., 2014; Appolos, Kwarbai, \& Ogundajo, 2016; Ogundajo \& Onakoya, 2016; Păunescu et al., 2016).However, the literature provides insufficient evidence on whether corporate governance attributes affects tax planning. An important aspect of corporate governance that may influence tax planning is top management financial expert. Board of directors and mangers accumulates knowledge through professional experience and continuous training, which can help them understand the opportunities available within the tax law. The financial expertise and tax knowledge of the directors and CEO may increase the likelihood of tax planning in an organization.

To mitigate the effect of tax on firm profitability and value, tax planning becomes imperative. But unfortunately, many organisations are unaware of these strategies. A good tax strategy increases company's financial performance by utilizing all the tax incentives within law. The incentives comprise of pioneer status, investment allowance, double taxation allowance, export allowances and exemptions among others. Therefore, the objective of this study is to examine the relationship between corporate governance attributes and tax planning of listed manufacturing companies and compare the ETR and tax paid between Nigeria and Malaysia listed companies.

Based on the objective we hypothesize that there is no significant relationship between corporate governance attributes and tax planning of listed manufacturing companies. 
The paper is structured as follows. Section 2 sets out a review of the literature on the issues around tax planning. Section 3 explains the research design and methodology employed. Section 4 present analysis and discussion of result. Finally, section 5 provides conclusion and recommendations.

\section{Literature Review and Theoretical Framework}

\subsection{Conceptual Clarification}

Tax planning is an integral part of financial planning and the decisions offers a tax manager and the company opportunity to mitigate the company's tax liability and improve on the financial performance of the firm(Ogundajo \& Onakoya, 2016).

Morien (2008) opined that in well-organized economies, paying taxes in business is unavoidable. Effective tax planning strategies can produce benefits in terms of wealth creation for the company. Hence, tax planning is a subset of the overall financial plan that comprise investment, financing and wealth creation strategies of the company. Tax planning involves the application of relevant incentive provisions for corporate tax payers based on enabling laws such as the CITA, PITA, VAT and other enactments. An in-depth understanding of the tax policies and other regulations as stated in the nation's government fiscal policies is required for effective tax planning. According toYusof, Noor and Mat Dangi, (2014)tax planning refers to how taxpayers manage and strategize to reduce their income tax burdens by utilizing the tax incentives given by the government within the boundaries of legal tax law.

Hanlon \& Heitzman, (2010)defined tax avoidance as the reduction of explicit taxes per dollar of pre-tax accounting earnings. However, there is no universally accepted definition of tax avoidance in the accounting literature. Under this broad definition, tax avoidance represents a continuum of tax planning strategies, encompassing activities that are perfectly legal (for instance, bond investments, capital allowances, use of debt financing) and more aggressive transactions that fall into the grey area such as abusive tax shelters, transfer pricing (TP), treaty shopping among others. Choog, (2007)opined that tax planning is crucial to achieve the objective of minimizing or deferring the income tax to a later year of assessment within the ambit of the law. Taxes take away greater proportion of the firms' earnings and subsequently reduce their distributable profit; this could be the reason why companies strive to engage in tax avoidance. Ayers, Call and Schwab (2018) documented that managers focus on tax avoidance that reduces financial statement tax expense, with a secondary motive in tax avoidance that enhances cash flows.

Mucai, Kinya, Noor and James (2014), opined that in order to ensure the efficiency and effectiveness of activities, and compliance with applicable laws, corporate enterprise need to have adequate tax controls. Corporate governance as internal monitoring mechanism will assist management in devising an effective tax planning that will improve the performance of the organization.

\subsection{Theoretical Framework}

Tax planning incorporates more dimensions of the agency conflict between managers and investors. Tax avoidance also creates another form of agency problem; managerial opportunism or resource diversion. Desai and Dharmapala (2006)argues that complex tax avoidance transactions can provide management with the tools and justifications for opportunistic managerial behaviors such as earnings manipulations, related party transactions and other resourcediverting activities. Tax planning has also been viewed as benefiting shareholders via increased after-tax earnings. It can be argued that tax planning can create information asymmetry between managers and shareholders. Therefore, agency theory underpinned this study.

\subsection{Empirical Review}

Taxes on corporate profits are mandatory and usually constitute a large outflow for firms in Nigeria and if not planned properly could lead to disproportionate and unwilling transfer of corporate resources to the government which may negatively impact on the operating capacity and value of the firms. Tax planning refers to how taxpayers manage and strategize to reduce their income tax burdens by utilizing the tax incentives given by the government within the boundaries of legal tax law (Yusof et al., 2014).

Ogundajo \& Onakoya (2016), empirically examined the influence of corporate tax planning on the financial performance of manufacturing firms quoted on NSE. They employed Generalized Least Square (GLS) method of 
regression and based on the outcome of Hausman model estimation test. They concluded that aggressive tax planning such as thin capitalization, tax law incentives and other benefits of loopholes in Nigerian tax laws have not been fully utilized by the Nigerian firms.

Appolos et al., (2016), examines the effect of tax planning on firm value of Nigerian Consumer Goods Industry. The study covered 50 firms for the period 2010-2014. Data were drawn from the published financial statements of the sampled companies and analyzed using descriptive and panel regression model. Their result reveals that Effective tax rate (ETR), Dividend (DIV) and Firm age (FAG) are positively and significantly related to firm value while firm size, leverage and tangibility exert negative effect on firm value. The study concluded that holistic approach to tax planning and optimal mix of tax planning strategies are important determinants of firm value.

In Kenya Mucai et al., (2014) investigates the relationship between tax planning and financial performance of smallscale enterprises. They found an influence of tax planning on performance of small-scale enterprise through capital structure, advertisement expenditure and investment in capital asset but found insignificant relationship between the legal forms of small-scale enterprises and tax planning.

Similarly, Yusof et al., (2014) examines corporate tax burden and financial attributes of Fraud Firms and Non-Fraud Firms in Malaysia. Their study examined the level of corporate ETR, the variation of corporate ETR from Statutory Tax Rate (STR) and the association between companies' financial attributes and ETR. Five financial attributes examined were firm size, leverage, returns on assets, capital intensity and inventory intensity. The statistical results revealed that fraud firms paid higher tax expense than the non-fraud firms. Further, the findings also indicate that return on assets and capital intensity were significantly associated with the variability of the corporate ETR.

Annuar et al., (2014), empirically investigates the relationship between corporate ownership structure and corporate tax avoidance in Malaysia. Two econometrics dynamic panel data models are proposed for the investigation and GMM estimation method was used. They argued based on cost and benefits consideration of tax avoidance that family, foreign and government ownerships could be associated with corporate tax avoidance among Malaysian listed companies. The study further proposes that strong governance mechanism could mitigate such association.

In the same veinNoor, Fadzillah and Mastuki, (2010), studied corporate effective tax rates (ETRs) of public companies listed on Bursa Malaysia during official assessment system and self-assessment system tax regimes. This study uses pooled sample data of 316 companies for the years 1993 to 2006. They found that corporate ETRs are below the statutory tax rate (STR) in both tax regimes. Furthermore, the study also examines the determinants of corporate ETRs during both tax regimes. The result supports political cost theory which suggests that larger companies endure higher ETRs and lower ETRs are significantly related to highly leverage companies, greater investment in fixed assets and lower investment in inventory. Their study also finds that companies with higher return on assets face lower ETRs.

Păunescu et al., (2016) explored the relationship between corporate governance characteristics and effective tax rate of US listed companies. Using a sample of 50 companies, mainly from the technology area, listed at NASDAQ over the period 2000- 2013 and panel data regression, as well as robustness checks by means of estimated generalized least squares and generalized method of moments. They found that board independence and board size have a statistically significant negative impact on effective corporate tax rate.

Abdul Wahab and Holland (2012), from a sample of UK quoted firms from 2005 to 2007 concludes a negative relationship between tax planning and firm value. Further, the relationship is robust to the inclusion of corporate governance measures which moderate the potential implications of a tax related shareholder-manager information asymmetry.

Bonu \& Pedro (2009) explored the impact of income tax rates on the economic development of Botswana. In their studies various parameters were considered including income tax rates, income tax revenue, total revenue and GDP of the country in the nominal and real value of money. They concluded that low income tax rates boost the economic growth of Botswana. 
Alan, Michael, Michael and John (2017), opined that the tax planning practices of companies, including U.S. multinational companies have been a source of considerable political and public concern worldwide. Gauging the extent of these practices is extremely difficult. Auerbach, Devereux, Keen and Vella (2017), documented a revenue loss from base erosion and profit shifting by multinationals of around 1 percent of gross domestic product (GDP) in OECD economies and more in others.

Miller (2017), argued that tax planning under an income tax system is based upon maximizing deductions and avoiding or deferring income. He concludes that many of the planning opportunities under the Destination Based Cash Flow Tax (DBCFT) arise because of its hybrid nature. The Blueprint promises a simpler tax code but a DBCFT won't be simpler than income tax. The new tax planning strategies will include generating deductions by making capital investments, exporting goods, using the earnings and profits rules to effectively deduct interest expense among others.

Gupta(2017), investigates multinational enterprises tax planning in relation to cross-border transactions and risk allocation practices in the light of the Organization for Economic Co-operation and Development (OECD)'s recent development and implementation of the base erosion and profit shifting (BEPS) action. His findings suggest that MNEs reduce or defer their tax liability by systematically moving intangibles within the MNE group and shifting income between related entities established in zero or low tax jurisdictions in the form of royalty payment.

Ayers et al. (2018), examined whether analysts cash flow forecasts encourage managers to enhance the firm's cash flow position through tax avoidance activities. They found a negative association between tax payments and analysts cash flow coverage. Further analysis suggests that the association is driven primarily by strategies to permanently avoid rather than to temporarily defer tax payments and that increased tax avoidance activity represents a nontrivial component of the overall increase in reported operating cash flows.

\section{Research Methodology}

This study employed ex-post facto and comparative research design. The population of this study comprises all the listed firms in the Nigerian Conglomerates sector which include AG LeventisNig Plc, Chellarams Plc, John Holt Plc, ScoaNig Plc, Transnational Corporation of Nig Plc and UAC of Nigeria Plc. The data for the study were obtained from the audited annual reports and accounts of these firms for the period of 5years from 2014- 2018. In addition, data were collected from the annual report and account of Bursa Malaysia Food and Beverages companies for the purpose of comparative analysis. The variables of the study comprised of dependent and independent variables. The independent variable is governance attributes proxied by board size (BSIZE) and CEO tenure (CEOTN), the dependent variable is tax planning proxied by effective tax rate (ETR) while firm size (FSIZE) was use as control variables.

Descriptive statisticsand Panel regression technique were used to analyze the data. The model specification of the study used to examine the relationship between corporate governance attributes and tax planning is stated as

$\mathrm{ETR}_{\text {it }}=\beta_{\mathrm{o}}+\beta_{1} \mathrm{BSIZE}_{\mathrm{it}}+\beta_{2} \mathrm{CEOT}_{\mathrm{it}}+\beta_{3} \mathrm{FSIZE}_{\mathrm{it}}+\mu_{\mathrm{it}}$

Where; ETR is the effective tax rate, $\beta_{0}$ represent the fixed intercept, $\beta 1-3$ is the coefficient of the independent variables, BSIZE denotes board size, CEOT denotes CEO tenure and FSIZE denotes firm sizewhile i represents the number of firms in the panel data, $t$ represents the time period of the panel data and $\mu$ is the error term.

\section{Result and Discussion}

\subsection{Descriptive Statistics}

The descriptive statistics is presented in Table 4.1 where minimum, maximum, mean and standard deviation of the data for the variables used in the study were described.

Table 4.1: Descriptive Statistics

\begin{tabular}{|l|l|l|l|l|}
\hline Var & Minimum & Maximum & Mean & Std. Dev \\
\hline ETR & 11.9 & 69.3 & 42.316 & 14.529 \\
BSIZE & 6 & 10 & 8 & 1.118 \\
CEOTN & 2 & 18 & 8.72 & 5.311 \\
FSIZE & 15.391 & 17.132 & 16.348 & 0.581 \\
\hline
\end{tabular}

Source: Author's Compilation, generated using STATA 
Table 4.1 provides a summary of the descriptive statistics of the dependent and explanatory variables. The mean effective tax rate of the firms is $42.3 \%$, the maximum rate is $69.3 \%$ whilethe minimum tax rate is $11.9 \%$ which indicate that on average tax expense account for about $42 \%$ of the operating profit of listed firms in the Nigerian conglomerate industry. The result also reveals that the average size of the board of listed Nigerian conglomerate companies is 8 directors with largest board having 10 directors and minimum board size of 6 directors. The average tenure of CEOs of listed Nigerian conglomerates companies is 9 years while the maximum tenure is 18 years within the study period. Table 4.2 shows the results of panel regression analysis on the relationship between corporate governance attributes and tax planning of listed Nigerian conglomerate companies.

\subsection{Regression Results}

This section presents the panel regression results of the dependent variables (ETR) and the independent variables of the study. The interpretation of the association between the variables individually and jointly was in the section.

Table 4.2: Regression Results

\begin{tabular}{|c|c|c|c|c|}
\hline \multicolumn{3}{|c|}{ Random effect } & \multicolumn{2}{|l|}{ Fixed effect } \\
\hline \multirow[t]{3}{*}{ Constant } & \multicolumn{2}{|c|}{$3.110^{* * *}$} & \multirow{3}{*}{$\begin{array}{c} \\
\\
\\
0.790) \\
0.347\end{array}$} & \multirow[t]{3}{*}{0.970} \\
\hline & $(316.98)$ & & & \\
\hline & 0.005 & & & \\
\hline \multirow[t]{3}{*}{ BSIZE } & & 0.760 & & 0.880 \\
\hline & (2.084) & & (3.792) & \\
\hline & 0.454 & & 0.392 & \\
\hline \multirow[t]{3}{*}{ CEOTN } & & $-2.220 * *$ & & -1.480 \\
\hline & $(-1.639)$ & & $(-1.619)$ & \\
\hline & 0.037 & & 0.157 & \\
\hline \multirow[t]{3}{*}{ FSIZE } & & $-2.740 * *$ & & -0.910 \\
\hline & $(-16.97)$ & & $(-13.04)$ & \\
\hline & 0.012 & & 0.377 & \\
\hline \multicolumn{2}{|l|}{ R-square } & 0.273 & & 0.236 \\
\hline \multicolumn{2}{|l|}{ F- value } & $2.620^{*}$ & & 2.100 \\
\hline \multicolumn{2}{|l|}{ P-value } & 0.0774 & & 0.1385 \\
\hline
\end{tabular}

Source: Author's Compilation, generated using STATA

*** and $* *$ indicate $1 \%$ and $5 \%$ significant levels respectively while in parenthesis is the coefficient, on top is the t- stat. and under is the pvalue.

The table above shows the results from the panel regression model which predict the relationship between BSIZE,CEOT, FSIZE and ETR. Hausman specification test was conducted to determine the best fitted model between the random effect and fixed effect estimation. The Chi-square value from the test is 0.14 and P-value of 0.9863 which is insignificant. Therefore, weinterpret the random effect estimation model. The result indicates a negative and significant relationship between CEOT, FSIZE and ETR anda positive relationship between BSIZE and ETR. The Rsquare is $27.2 \%$ which indicates the variation in tax planning that is explained by the board size and CEO tenure while $72.8 \%$ of the variation is attributable to factors outside the study model. The hypothesis of the study predicts that there is no significant relationship between corporate governance and tax planning of listed firms in the Nigerian conglomerate Industry. From the result of the regression analysis the F-statistics is 2.620 while the P-value is 0.0774 which is significant at 10 percent. Therefore, this provides an evidence for rejecting the null hypothesis and concluding that there is a significant relationship between corporate governance attribute and tax panning of listed companies in the Nigeria conglomerate Industry.The findings of this study are consistent among others.

\subsection{Comparative Analysis}

Table 4.3 present the comparative analysis of the effective tax rate and the tax paid by the listed companies from both Nigeria and Malaysia. 
Table 4.3: Comparative results

\begin{tabular}{|l|l|l|l|l|}
\hline & Nigeria & Malaysia \\
\hline Var & ETRn & TAXn & ETRm & TAXm \\
\hline Min & 11.9 & 2797 & 5.1 & 4200 \\
Max & 69.3 & 543000 & 33.8 & 24500 \\
Mean & 42.316 & 172130.3 & 23 & 11924 \\
Std. Dev & 14.529 & 194318.1 & 6.915 & 5035.398 \\
\hline \multicolumn{5}{|c}{ Source: Author's Compilation, generated using STATA } \\
Effective tax rate in \% and Tax paid in Millions
\end{tabular}

From the comparative statistics in table 4.3, the minimum tax rate of listed Nigeria conglomerate companies is $11.9 \%$ while the maximum tax rate is $69.3 \%$ and the maximum amount of tax liability is N543000000. In comparism the minimum tax rate of Bursa Malaysia food and beverages companies is 5.1\% while the maximum tax rate is $33.8 \%$ and the maximum amount that is paid as tax expense is $\mathrm{Rm} 24500000$. Further the above result shows Nigerian listed companies are paying higher amount of tax charges from their operating income as compared with their Malaysian counterpart. The results is in line with the study of (Noor et al., 2010), that revealed that Malaysian corporate tax system provide a substantial amount of tax incentives to companies, thus encouraging the companies to engage in aggressive tax planning. Therefore, the board of directors and the chief executive officers of public companies need to pay more attention to tax planning to be able to minimize their tax burden and increase their net income.

\section{Conclusion}

This study examines the relationship between corporate governance attributes and tax planning and the comparative analysis of tax charges between Nigeria and Malaysia. The result indicates a negative and significant relationship between CEOT, FSIZE and ETR and a positive relationship between BSIZE and ETR. Our overall conclusion is that corporate governance mechanism plays a key role in tax planning and Nigerian manufacturing companies pays high tax charges as compare to Malaysian food and beverages companies. Although, tax planning can increase netprofit, but companies need to also consider the actual and potential cost associated with tax avoidance. Tax authorities should also undertake tax audit and investigation to trace illegal tax activities that may lead to tax evasion.

\section{Reference}

Abdul Wahab, N. S., \& Holland, K. (2012). Tax planning, corporate governance and equity value. British Accounting Review, 44(2), 111-124. https://doi.org/10.1016/j.bar.2012.03.005

Annuar, H. A., Salihu, I. A., \& Obid, S. N. S. (2014). Corporate Ownership, Governance and Tax Avoidance: An Interactive Effects. Procedia - Social and Behavioral Sciences, 164(August), 150-160. https://doi.org/10.1016/j.sbspro.2014.11.063

Appolos, N., Kwarbai, J., \& Ogundajo, G. (2016). Tax Planning and Firm Value: Empirical Evidence from Nigerian Consumer Goods Industrial Sector. Research Journal of Finance and Accounting, 7(12), 2222-2847.

Auerbach, A. J., Devereux, M. P., Keen, M., \& Vella, J. (2017). International tax planning under the destination-based cash flow tax. National Tax Journal, 70(4), 783-802. https://doi.org/10.17310/ntj.2017.4.04

Ayers, B. C., Call, A. C., \& Schwab, C. M. (2018). Do Analysts' Cash Flow Forecasts Encourage Managers to Improve the Firm's Cash Flows? Evidence from Tax Planning. Contemporary Accounting Research, 35(2), 767-793. https://doi.org/10.1111/1911-3846.12403

Bonu, N. S., \& Pedro, M. P. (2009). The impact of income tax rates ( ITR ) on the economic development of Botswana. Journal of Accounting and Taxation, 1(1), 8-22.

Choog, F. K. (2007). Advanced Malaysian Taxation: Principles and Practice (8th Ed.). Malaysia: InfoWorld.

Dennis, A., \& Emmanuel, O. (2014). The Impact of Taxation on Revenue Generation in Nigeria: A Study of Federal Capital Territory and Selected States. International Journal of Public Administration and Management Research, 2(2), 22-47.

Desai, M. A., \& Dharmapala, D. (2006). Corporate tax avoidance and high powered incentives. Journal of Financial Economics, 79(1), 145-179.

Gupta, R. (2017). Analysis of Intellectual Property Tax Planning Strategies of Multinationals and the Impact of the BEPS Project. Australian Tax Forum, 33(August 2017), 185-220.

Hanlon, M., \& Heitzman, S. (2010). A review of tax research. Journal of Accounting and Economics, 50, $127-178$.

KPMG. (2018). Nigerian Tax. Nigerian Tax Journal, (February), 1-36. 
Miller, D. S. (2017). Tax Planning under the Destination based cash flow tax: A guide to policy makers practitioners. Columbia Journal of Tax Law, 8, 295-308.

Mucai, G. P., Kinya, G. S., Noor, A. I., \& James, E. R. (2014). Tax planning and financial performance of small scale enterprises in Kenya. International Review of Management and Business Research, 3(2), 1236-1243.

Noor, R. M., Fadzillah, N. S. M., \& Mastuki, N. (2010). Corporate Tax Planning: A Study On Corporate Effective Tax Rates of Malaysian Listed Companies. International Journal of Trade, Economics and Finance, 1(2), 189193. https://doi.org/10.7763/ijtef.2010.v1.34

Ogundajo, G. O., \& Onakoya, A. B. (2016). Tax Planning and Financial Performance of Nigerian Manufacturing Companies. International Journal of Advanced Academic Research Social \& Management Sciences, 2(7), 6480.

Păunescu, R. A., Vintilă, G., \& Gherghina, Ş. C. (2016). Exploring the Link between Corporate Governance Characteristics and Effective Corporate Tax Rate: A Panel Data Approach on U.S. Listed Companies. Journal of Financial Studies and Research, (October), 1-16. https://doi.org/10.5171/2016.857506

Yusof, A. M. M., Noor, R., \& Mat Dangi, M. R. (2014). Corporate Tax Burden and Financial Attributes of Frauf Firms and Non-Fraud Firms In Malaysia. Gading Business and Management Journal, 18(January 2017), 77100. 